\title{
Otomatisasi Lampu, Tirai, dan Kipas Angin Menggunakan Mikrokontroler untuk Menghemat Energi Listrik
}

\author{
Automation of Lights, Curtains, and Fan Using \\ Microcontroller for Saving Electrical Energy
}

\author{
Wida Lidiawati $^{\mathrm{a},{ }^{*}, \text { Lia Muliani Pranoto }}{ }^{\mathrm{b}}$, Waslaluddin ${ }^{\mathrm{a}}$, dan Jojo Hidayat ${ }^{\mathrm{b}}$ \\ ${ }^{a}$ Fisika, FPMIPA, Universitas Pendidikan Indonesia. \\ Jl. Dr. Setiabudhi No. 229, Bandung 40154, Indonesia \\ ${ }^{b}$ Pusat Penelitian Elektronika dan Telekomunikasi, Lembaga Ilmu Pengetahuan Indonesia. \\ Komp LIPI Gd 20, Jl Sangkuriang 21/54D, Bandung 40135, Indonesia
}

\begin{abstract}
Abstrak
Kebutuhan energi listrik saat ini terus mengalami peningkatan. Hal ini disebabkan karena jumlah penduduk yang semakin meningkat dan pertumbuhan ekonomi. Saat ini, untuk memenuhi kebutuhan energi listrik, eksploitasi terhadap sumber-sumber energi berbasis fosil terus dilakukan padahal ketersediaan di alam semakin berkurang. Hal ini masih diperparah oleh pemborosan energi, baik yang dilakukan pada tingkat rumah tangga, perkantoran, maupun industri. Oleh karena itu, pada penelitian ini, dilakukan otomatisasi pada perangkat listrik, dalam hal ini, lampu, tirai, dan kipas angin untuk mengoptimalkan pemanfaatan energi listrik. Lampu yang digunakan berupa Light Emitting Diode (LED) dan pergerakan tirai serta kipas diatur oleh motor DC. Pada sistem otomatisasi dibuat rangkaian sensor dengan menggunakan Light Dependent Resistor (LDR). Tegangan keluaran dari LDR akan diolah oleh mikrokontroler untuk mengaktifkan aktuator, dalam hal ini LED dan motor DC. Dengan sistem otomatisasi, energi yang digunakan dapat dihemat $50 \%$.
\end{abstract}

Kata Kunci: LDR, mikrokontroler, LED, motor DC.

\section{Abstract}

Population and economic growth cause electrical energy to increase. To fulfill electrical energy, exploitation of the resources of fossil continue to be made whereas availability in nature is limited. This is compounded by the waste of energy, whether conducted at the household level, offices, and industries. Therefore, this study make automation of electrical devices, in this case, lamp, curtain, and fan to optimize the utilization of electrical energy. Lamps used in the form of Light Emitting Diode (LED). Curtain and fan be moved by DC motor. For automation system, Light Dependent Resistor (LDR) is used as sensor. The output voltage of the LDR will be processed by the microcontroller to activate the actuator, in this case the LED and DC motors. With the automation system, $50 \%$ energy used can be saved.

Keywords: LDR, microcontroller, LED, DC motor.

\section{Pendahuluan}

Pertumbuhan penduduk dan ekonomi menyebabkan kebutuhan energi listrik saat ini terus mengalami peningkatan. Untuk memenuhi kebutuhan energi listrik, eksploitasi terhadap sumber-sumber energi berbasis fosil, seperti minyak bumi dan batu bara terus dilakukan. Ketersediaan sumber-sumber energi berbasis fosil di alam semakin lama akan semakin berkurang dan lambat laun akan habis sama sekali karena sumbersumber energi fosil merupakan sumber energi yang tidak dapat diperbaharui. Oleh karena itu, perlu dilakukan pengembangan terhadap sumber energi terbarukan dan berkelanjutan seperti panas bumi, biomassa, air, gelombang laut atau ombak, angin, dan matahari.

\footnotetext{
* Corresponding Author.

Email: wida_lidiawati@yahoo.com

Received: November 25, 2013; Revised: Desember 9, 2013

Accepted: Desember 23, 2013

Published: Desember 30, 2013

(C) 2013 PPET - LIPI

doi : $10.14203 /$ jet.v13.66-72
}

Indonesia merupakan negara yang terletak di daerah khatulistiwa sehingga energi surya merupakan energi potensial dikembangkan di Indonesia. Energi surya memiliki keunggulan-keunggulan dibandingkan dengan energi fosil, diantaranya sumber energi yang mudah didapatkan, ramah lingkungan, sesuai untuk berbagai macam kondisi geografis, instalasi dan perawatan mudah, listrik dari energi surya dapat disimpan dalam baterai. Energi radiasi matahari diubah menjadi listrik dengan mempergunakan pembangkit listrik tenaga surya dengan teknologi photovoltaic yang terbuat dari bahan semikonduktor yang disebut solar cell [1].

Selain mengembangkan energi terbarukan, akan lebih baik lagi jika tidak melakukan pemborosan energi. Energi listrik sering kali tidak dimanfaatkan dengan baik oleh manusia. Contohnya, lampu dan pendingin ruangan ( $\mathrm{AC}$ atau kipas angin) tetap dibiarkan menyala padahal tidak digunakan. Atas dasar itulah otomatisasi lampu dan kipas angin dilakukan. Sedangkan otomatisasi pada tirai dimaksudkan supaya ruangan selalu mendapatkan cahaya. 
Keyza [2] telah melakukan perancangan prototipe sistem penerangan otomatis ruangan berjendela berdasarkan intensitas cahaya. Sistem penerangan otomatis berdasarkan intensitas cahaya terdiri dari perangkat keras dan perangkat lunak yang digabungkan menjadi satu kesatuan dalam maket yang telah dibuat. Mikrokontroler akan mengaktifkan keseluruhan sistem saat mendeteksi adanya manusia yang masuk ke dalam ruangan. Mikrokontroler menerima dan mengolah input dari sensor cahaya yang diletakkan telah dipasang di dalam maket. Kemudian mikrokontroler akan memberikan respon berupa output untuk menggerakkan tirai blinds dan mengatur arus lampu untuk penerangan ruangan.

\section{Tinjauan Pustaka}

\section{A. Fotoresistor}

Fotoresistor atau sering juga disebut sebagai Light Dependent Resistor (LDR) adalah resistor yang mempunyai nilai resistansi yang berubah sesuai dengan intensitas cahaya tampak yang menimpanya. Elemen pada LDR terbuat dari kadmium sulfida $(\mathrm{CdS})$ yang peka terhadap cahaya tampak. Jika LDR terkena cahaya maka nilai tahanan akan menjadi besar sekitar $10 \mathrm{M} \Omega$ dan jika terkena cahaya nilai tahanan akan menjadi kecil sekitar $1 \mathrm{k} \Omega$ [2], [3].

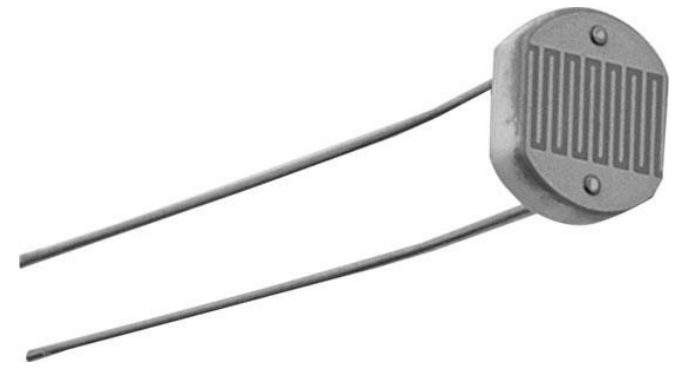

Gambar 1. Fotoresistor.

Cara kerja LDR adalah sebagai berikut. Di bawah cahaya yang redup, bahan piringan hanya mengandung elektron bebas dalam jumlah yang relatif sangat kecil. Hanya tersedia sedikit elektron bebas untuk mengalirkan muatan listrik. Hal ini berarti bahwa bahan bersifat sebagai konduktor yang buruk untuk arus listrik. Dengan kata lain, nilai tahanan bahan sangat tinggi. Sedangkan di bawah cahaya yang cukup terang, terdapat lebih banyak elektron bebas yang dapat mengalirkan muatan listrik. Dalam keadaan ini, bahan bersifat sebagai konduktor yang baik [4].

\section{B. Mikrokontroler ATmega 8535}

ATmega 8535 yang merupakan produksi ATMEL yang berjenis AVR memiliki fitur 32 saluran I/O yang terdiri dari empat Port (Port A, Port B, Port C, dan Port D) yang masing-masing terdiri dari 8 bit, Analog to Digital Converter (ADC) 10 bit (8 pin di Port A.0 sampai Port A.7), dua buah timer/counter 8 bit, satu buah timer/counter 16 bit, empat buah channel PWM, enam buah modus sleep (Idle, ADC, Noise Reduction, Power-save, Standby, dan Extended Standby), komparator analog, watchdog timer dengan osilator External $1 \mathrm{MHz}$, memori $8 \mathrm{~KB}$ flash, memori 512 byte Static Random-Access Memory (SRAM), memori 512 byte Electrically Erasable Programmable Read-Only Memory (EEPROM), kecepatan maksimal $16 \mathrm{MHz}$, tegangan operasi 4,5-5,5 VDC, 32 jalur I/O yang dapat diprogram, interupsi internal dan eksternal, komunikasi serial menggunakan Port Universal Synchronous Asynchronous Receiver Transmitter (USART) dengan kecepatan maksimal 2,5 Mbps, pemrograman langsung dari port paralel komputer [5].

Pada ATmega 8535, ADC terintegrasi dalam satu IC monolitik. Fitur ADC merupakan bentuk tambahan dari pengembangan IC mikrokontroler dari keluarga jenis AVR. Proses konversi data pada ADC dilakukan dengan cara mengubah tegangan analog menjadi data tegangan biner 10-bit [6].

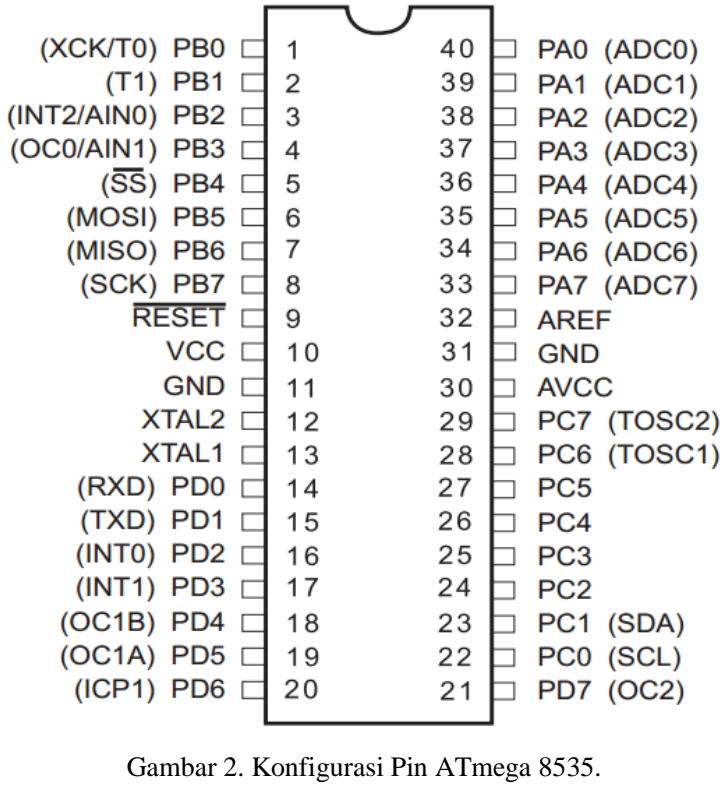

\section{Light Emitting Diode (LED)}

LED merupakan komponen yang dapat mengeluarkan emisi cahaya. LED merupakan produk temuan lain setelah dioda. Strukturnya sama dengan dioda, tetapi belakangan ditemukan bahwa elektron yang menerjang sambungan p-n juga melepaskan energi panas dan energi cahaya. Karakteristik LED sama dengan karakteristik dioda penyearah. Bedanya jika dioda membuang energi dalam bentuk panas, sedangkan LED membuang energi dalam bentuk cahaya [5].

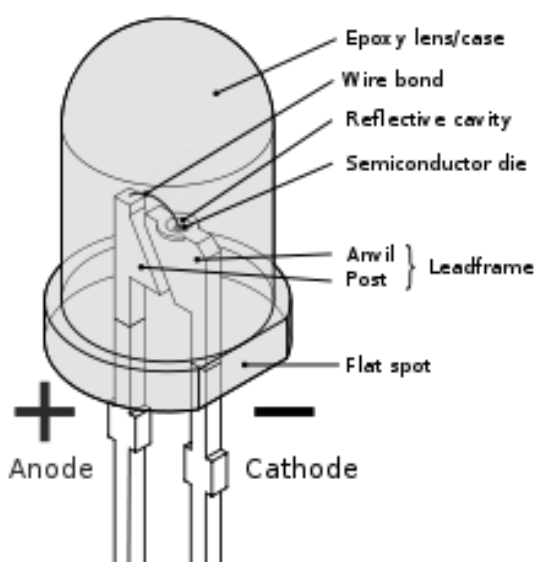

Gambar 3. LED. 


\section{Driver Motor DC}

Salah satu contoh driver motor DC adalah IC L293D. IC ini mempunyai tiga buah input, yaitu IN1, IN2, dan Enable. Pada IC ini terdapat dua jembatan-H yang dapat digunakan untuk dua buah motor. Sebuah rangkaian $\mathrm{H}$-Bridge terdiri dari dua buah pin input (IN1 dan IN2 atau IN3 dan IN4), satu pin enable (ENABLE1 atau ENABLE2) dan dua buah pin output (OUT1 dan OUT2 atau OUT3 dan OUT4). [3]

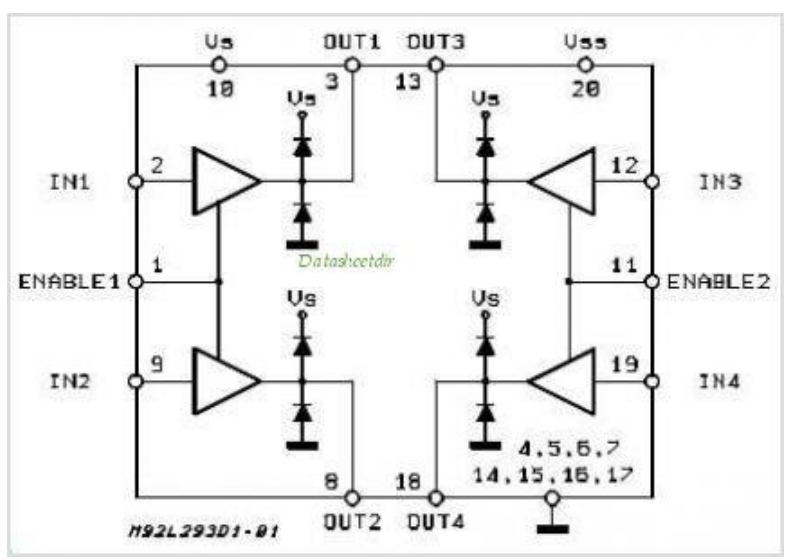

Gambar 4. Datasheet L293D.

\section{E. Motor DC}

Motor DC digunakan pada banyak aplikasi karena relatif mudah dalam pengendaliannya. Kecepatan motor DC dapat diatur dan semua motor DC putarannya dapat dibalik. Komponen utama dari motor DC adalah komutator, sikat (brushes), dan magnet [3].

Prinsip kerja motor DC berdasar pada penghantar yang membawa arus ditempatkan dalam suatu medan magnet. Penghantar akan mengalami gaya dapat dijelaskan pada sebuah kawat berarus yang dihubungkan pada kutub magnet utara dan selatan.Arah gaya dapat ditentukan dengan menggunakan kaidah tangan kiri. Apabila suatu kumparan jangkar (rotor) dialiri arus listrik dalam suatu medan magnet maka akan terbangkit gaya (pada rotor tersebut) sebesar [7].

$$
\boldsymbol{F}=\boldsymbol{B} \boldsymbol{i} \boldsymbol{L}
$$

di mana

$F=$ gaya $(\mathrm{N})$

$B=$ medan magnet $(\mathrm{T})$

$i=\operatorname{arus}$ listrik (A)

$L=$ panjang kumparan (m)

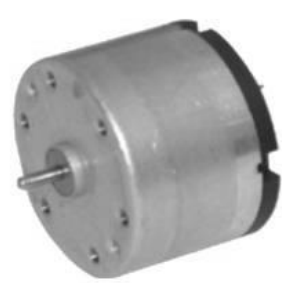

Gambar 5. Motor DC.

\section{F. Akumulator}

Akumulator adalah salah satu elemen sumber arus listrik searah. Akumulator termasuk elemen elektrokimia yang dapat diperbarui bahan pereaksinya setelah dialiri arus dari sumber lain yang arahnya berlawanan dengan arus yang dihasilkan elemen tersebut. Yang dimaksud dengan elemen elektrokimia adalah sistem sumber arus yang pada dasarnya mengubah energi kimia menjadi energi listrik. Di dalam sumber ini terjadi reaksi oksidasi reduksi sehingga menimbulkan elektron bebas yang dapat terus-menerus mengalir selama jangka waktu tertentu jika kutub-kutub sumber ini berada dalam keadaan tertutup [8].

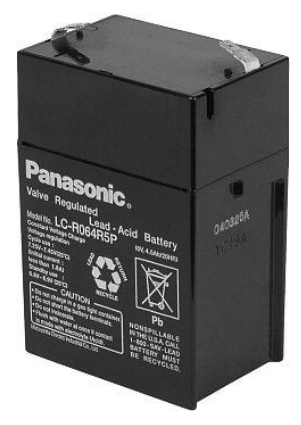

Gambar 6. Akumulator

\section{Perancangan Sistem}

Prosedur penelitian ini dibagi menjadi beberapa tahap, yaitu tahap persiapan, tahap perancangan, dan tahap pembuatan. Tahap persiapan merupakan ide awal sistem yang diikuti dengan mencari literatur dari berbagai sumber. Tahap perancangan adalah merancang sistem secara keseluruhan yang akan diaplikasikan pada tahap pembuatan. Tahapan-tahapan secara keseluruhan dapat ditunjukkan pada Gambar 7:

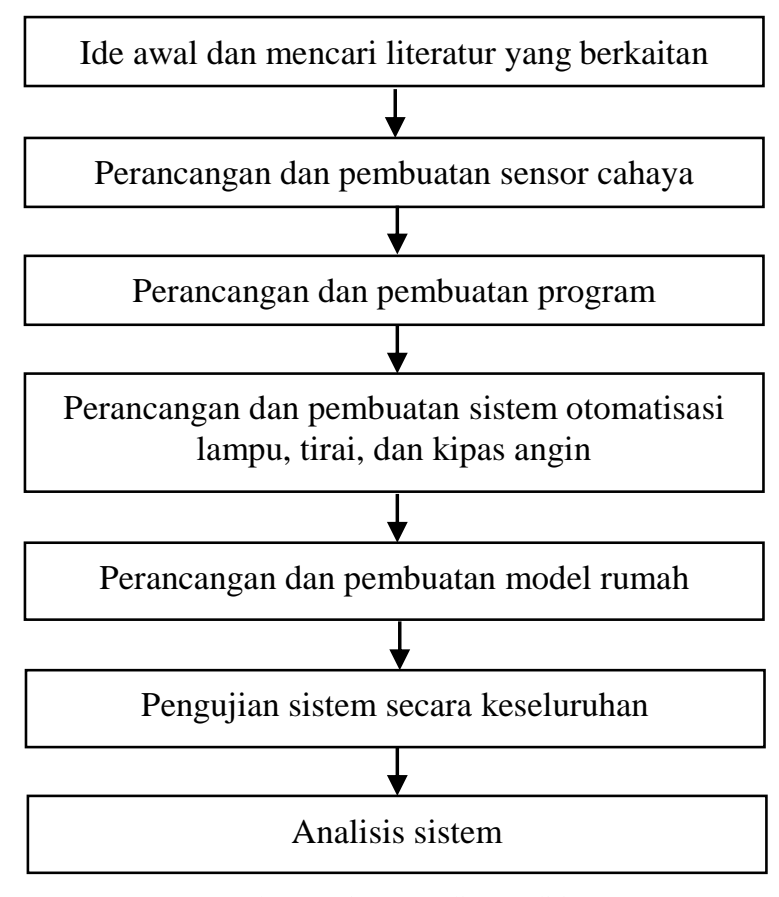

Gambar 7. Diagram Alir Penelitian

Pada tahap perancangan, dilakukan perancangan pada konstruksi mekanik, sensor cahaya, dan sistem kontrol seperti dijelaskan sebagai berikut:

\section{A. Sistem Mekanik}

Sistem mekanik diperlukan untuk menggerakkan tirai dan kipas angin. Tirai digerakkan oleh motor DC yang dapat berputar searah jarum jam dan berlawanan 
arah jarum jam. Sistem mekanik pada tirai menggunakan pulley dan benang yang dihubungkan dengan motor DC. Sedangkan untuk kipas angin, motor DC dihubungkan sepusat dengan baling-baling sehingga baling-baling akan mengikuti pergerakan motor DC.

\section{B. Sensor Cahaya}

Pada perancangan sensor cahaya, hal yang diperhatikan adalah resistansi LDR ketika kondisi gelap dan terang. Kemudian perlu ditentukan nilai tegangan referensi untuk menggambarkan apakah keadaan ruangan terang atau gelap. Tegangan referensi ini dapat diperoleh dari data intensitas dan tegangan yang diambil dari pagi hari sampai sore hari.

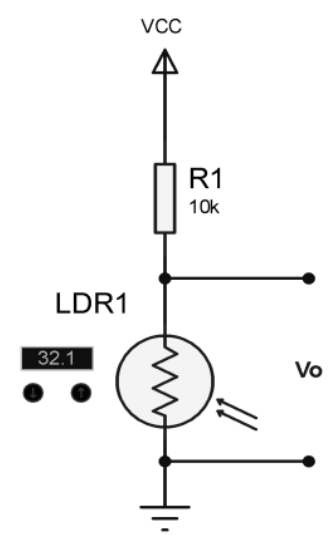

Gambar 8. Rangkaian Sensor Cahaya.
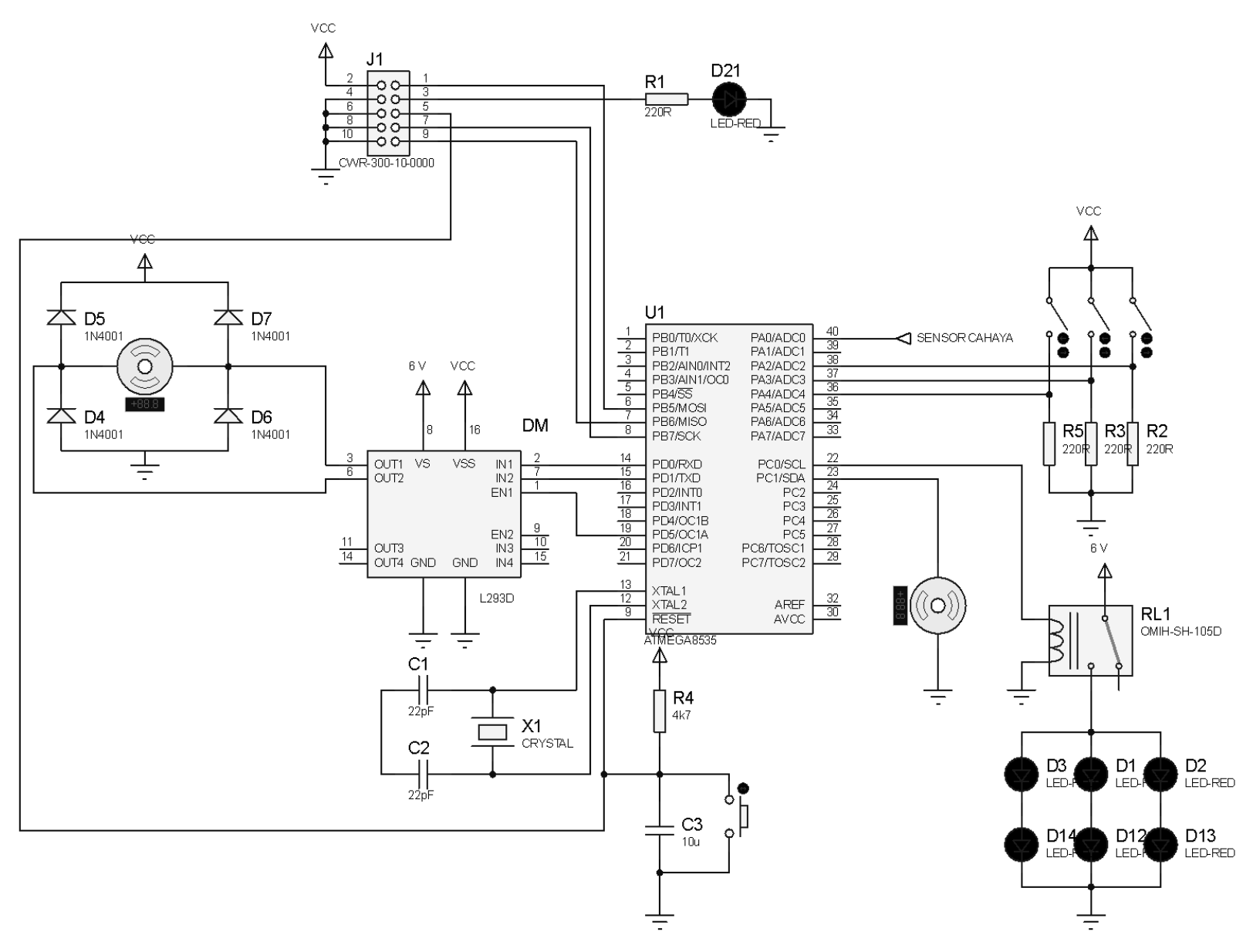

Gambar 9. Rangkaian Sistem Otomatisasi..

\section{Driver Motor DC}

Driver yang digunakan adalah L293D. Pada motor $\mathrm{DC}$, driver ini digunakan untuk menggerakkan motor, mengatur arah putaran motor DC, menghentikan motor, dan melindungi motor dari kerusakan elektronik. Driver ini dikendalikan oleh mikrokontroler yang telah diinjeksikan program di dalamnya. Driver ini memiliki dua input power yaitu Vcc yang berfungsi sebagai power untuk IC L293D dan input power motor DC. Dua input power ini berfungsi karena IC bekerja pada tegangan kerja $5 \mathrm{~V}$ sedangkan motor DC biasanya mempunyai tegangan kerja 6-36 V.

\section{Sistem Kontrol}

Sedangkan pada sistem kontrol, sebelumnya perlu dibuat sistem minimum supaya mikrokontroler dapat bekerja. Untuk membuat sistem minimum, pin VCC dan AVCC pada mikrokontroler dihubungkan ke $+5 \mathrm{~V}$, pin GND dan AGND dihubungkan ke ground, serta pin reset tidak dihubungkan apa-apa atau dapat menggunakan push button untuk memaksa pin RESET menjadi nol. Kristal eksternal dihubungkan pada pin XTAL1 dan XTAL2. [9] Setelah sistem minimum, maka dibuat pula jalur untuk input output antara sensor, mikrokontroler, LED, dan driver motor DC yang ditunjukkan Gambar 9. 
Sebelum membuat program yang akan diinjeksikan ke dalam mikrokontroler, terlebih dahulu dibuat flowchart supaya tidak ada langkah yang terlewat. Berikut flowchart (Gambar 10) dalam sistem yang akan dibuat:

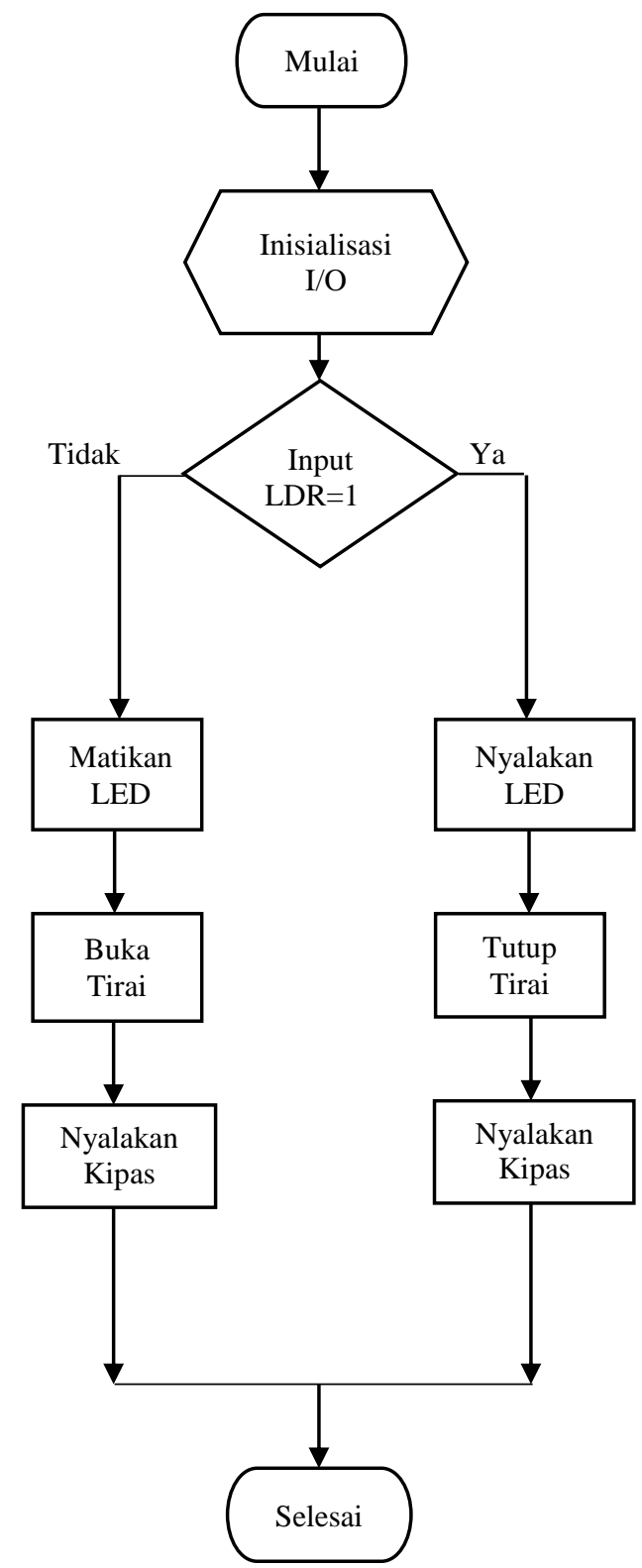

Gambar 10. Diagram Alir Program.

Program dibuat dan diinjeksikan ke dalam mikrokontroler menggunakan software CodeVisionAVR. CodeVisionAVR adalah sebuah compiler $\mathrm{C}$ yang telah dilengkapi dengan fasilitas Integrated Development Environment (IDE) dan didesain agar dapat menghasilkan kode program secara otomatis untuk mikrokontroler Atmel AVR. IDE telah dilengkapi dengan fasilitas pemrograman chip melalui metode InSystem Programming sehingga dapat secara otomatis mentransfer file program ke dalam chip mikrokontroler AVR setelah sukses dikompilasi [10].

\section{Hasil dan Pembahasan}

Pengujian alat dilakukan dengan menggabungkan seluruh rangkaian yang digunakan, yaitu rangkaian catu daya, sensor, dan mikrokontroler. Pada pengujian alat dilakukan pengukuran terhadap tegangan masukan dan tegangan keluaran sistem. Sedangkan untuk mengetahui daya pada beban dilakukan pengukuran arus yang digunakan oleh beban untuk selanjutnya dilakukan perhitungan. Tabel 1 berikut adalah data yang dihasilkan:

TABEL I

DATA PEMAKAIAN DAYA PADA BEBAN

\begin{tabular}{|l|c|c|c|}
\hline & $\begin{array}{c}\text { Arus } \\
(\mathbf{A})\end{array}$ & $\begin{array}{c}\text { Tegangan } \\
(\mathbf{V})\end{array}$ & $\begin{array}{c}\text { Daya } \\
\text { (Watt) }\end{array}$ \\
\hline Lampu & 0,14 & 6,00 & 0,84 \\
\hline Tirai & 0,58 & 6,00 & 3,48 \\
\hline Kipas Angin & 0,44 & 6,00 & 2,64 \\
\hline Mikrokontroler & 0,11 & 6,00 & 0,66 \\
\hline Total & & & 7,62 \\
\hline
\end{tabular}

\section{A. Catu Daya}

Catu daya yang digunakan adalah akumulator $6 \mathrm{~V}$, 4,5 Ah. Akumulator diisi melalui energi yang disalurkan oleh modul surya. Pengujian dilakukan untuk mengetahui besar tegangan yang dihasilkan oleh akumulator yang akan digunakan untuk LED dan motor DC. Selain itu, pengujian juga dilakukan untuk mengetahui besar tegangan akumulator yang telah diregulasi menggunakan LM 7805 yang akan digunakan sebagai sumber tegangan pada rangkaian sensor, mikrokontoler ATmega 8535, dan input Vss driver L293D. Berikut ini hasil pengukuran yang ditunjukkan pada Tabel 2.

TABEL II

HASIL PENGUKURAN CATU DAYA

\begin{tabular}{|c|c|c|c|}
\hline No. & $\begin{array}{c}\text { Vaccu } \\
\text { (volt) }\end{array}$ & $\begin{array}{c}\text { Vmikro } \\
\text { (volt) }\end{array}$ & $\begin{array}{c}\text { Vsensor } \\
\text { (volt) }\end{array}$ \\
\hline 1 & 6,00 & 4,53 & 4,59 \\
\hline 2 & 6,01 & 4,53 & 4,57 \\
\hline 3 & 5,99 & 4,53 & 4,58 \\
\hline 4 & 6,01 & 4,53 & 4,56 \\
\hline 5 & 6,00 & 4,53 & 4,52 \\
\hline Rata-rata & 6,00 & 4,53 & 4,56 \\
\hline
\end{tabular}

Besar tegangan akumulator rata-rata sebesar $6 \mathrm{~V}$.

Tegangan ini sudah mampu untuk menggerakkan motor DC dan menyalakan LED yang telah disusun seriparalel. Besar tegangan yang dikeluarkan IC LM 7805 untuk dijadikan tegangan masukan pada mikrokontroler rata-rata 4,53 V sedangkan pada rangkaian sensor 4,56 V. Tegangan tersebut sudah mampu membuat mikrokontroler bekerja karena tegangan kerja mikrokontroler adalah antara 4,5 V sampai 5,5 V [9].

\section{B. Rangkaian Sensor}

Rangkaian yang digunakan pada sensor cahaya memanfaatkan prinsip perbandingan tegangan, yaitu antara tegangan referensi dengan tegangan keluaran sensor.

Berdasarkan data yang telah diperoleh, antara pukul 05.45-05.50 WIB dengan intensitas 7-8 $\mathrm{mW} / \mathrm{cm} 2$ keadaan ruangan sudah cukup terang sehingga dapat dijadikan sebagai titik acuan. Dengan demikian, jika intensitas cahaya lebih rendah dari titik acuan maka dapat dikatakan gelap sedangkan jika intensitas cahaya lebih tinggi dari titik acuan maka dapat dikatakan terang. 
TABEL III

TEgANGAN KELUARAN RANGKAIAN SENSOR

\begin{tabular}{|c|c|c|}
\hline \multirow{2}{*}{ No. } & Terang & Gelap \\
\cline { 2 - 3 } & Vout $(\mathbf{m V})$ & Vout $($ Volt) \\
\hline 1 & 3,80 & 3,71 \\
\hline 2 & 3,60 & 3,70 \\
\hline 3 & 3,50 & 3,71 \\
\hline 4 & 3,70 & 3,72 \\
\hline 5 & 3,50 & 3,75 \\
\hline Rata-rata & 3,62 & 3,72 \\
\hline
\end{tabular}

Berdasarkan Tabel 3 keluaran sensor sudah dapat bekerja dengan baik walaupun tegangan keluarannya tidak mencapai nilai Vcc. Namun, dengan tegangan keluaran yang dihasilkan sudah dapat memberikan logika 1 dan 0 pada mikrokontroler karena berdasarkan datasheet tegangan input mikrokontroler akan bernilai high (1) jika berada pada rentang 0,6 Vcc sampai Vec+0,5 dan bernilai low (0) jika berada pada rentang $0,5 \mathrm{~V}$ sampai $0,2 \mathrm{Vcc}$ [9].

\section{Sistem Kontrol}

Mikrokontroler ATmega 8535 digunakan sebagai pengendali pada otomatisasi lampu, kipas angin, dan tirai. Sensor cahaya akan menghasilkan tegangan ketika ada intensitas cahaya yang menimpanya. Tegangan yang dihasilkan sensor kemudian masuk ke mikrokontroler untuk diolah. Sebelumnya, mikrokontroler diinjeksikan program sehingga dapat bekerja sesuai yang diinginkan. Keluaran mikrokontroler akan direpresentasikan oleh LED yang berfungsi sebagai lampu dan motor DC yang berfungsi sebagai penggerak pada tirai dan kipas angin.

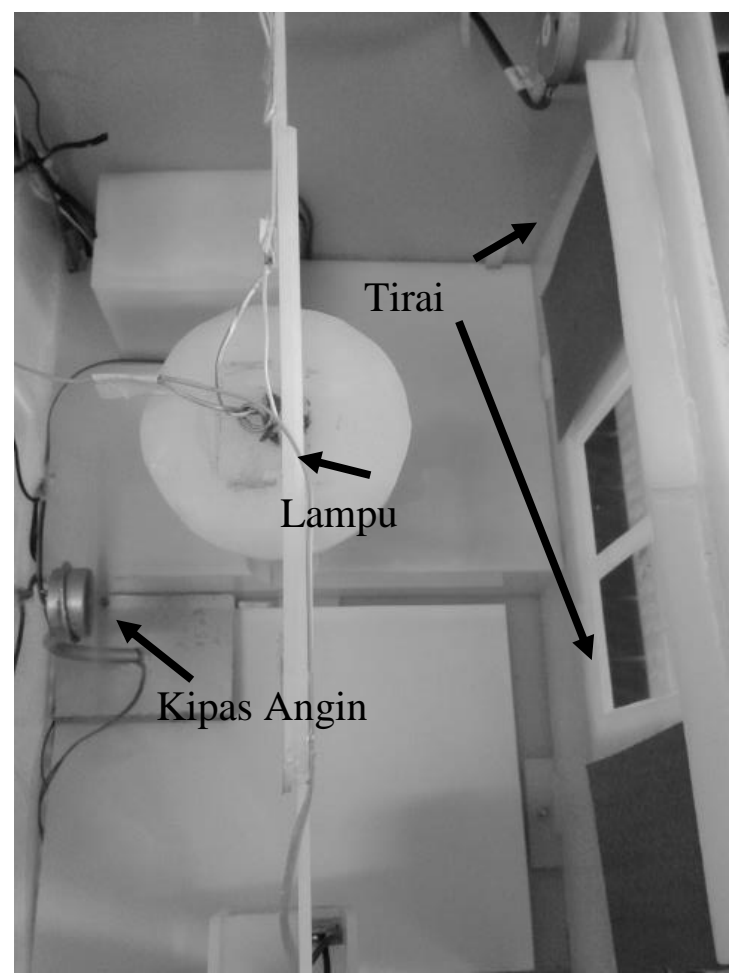

Gambar 11. Lampu, Tirai, dan Kipas Angin pada Maket.

Berdasarkan hasil pengamatan yang dilakukan, lampu menyala ketika kondisi gelap. Sedangkan lampu padam ketika kondisi terang. Pergerakan tirai dan kipas angin mengikuti nyala atau padamnya lampu. Ketika lampu padam, tirai terbuka, dan kipas angin menyala, dan demikian sebaliknya.

Sistem kontrol sudah berjalan dengan baik karena tegangan input maupun tegangan output mikrokontroler masih berada pada rentang yang diperbolehkan. Hal ini dapat dilihat di datasheet ATmega 8535. Tegangan input low (VIL) pada mikrokontroler adalah antara $-0,5$ $\mathrm{V}$ sampai $0,22 \mathrm{Vcc}$, tegangan input High (VIH) adalah antara $0,6 \mathrm{Vcc}$ sampai $0,5+\mathrm{Vcc}$, tegangan output low (VOL) maksimal $0,7 \mathrm{~V}$, dan tegangan output high (VOH) minimal 4,2 V [9].

\section{Efisiensi Pemanfaatan Lampu, Tirai, dan Kipas Angin Otomatis}

Untuk mengetahui optimalisasi sistem maka diasumsikan sistem digunakan selama satu hari ketika tidak ada orang di rumah dan tirai tidak diabaikan karena tirai hanya digunakan dalam hitungan detik. Maka, dengan sistem otomatisasi, energi yang digunakan adalah sebagai berikut:

$$
\begin{aligned}
& \text { Lampu } \rightarrow 1,5 \mathrm{~W} \times 12 \mathrm{~h}=18 \mathrm{Wh} \\
& \text { Kipas Angin } \rightarrow 3.3 \mathrm{~W} \times 12 \mathrm{~h}=39,6 \mathrm{Wh} \\
& \text { Total pemakaian energi adalah } 57,6 \mathrm{Wh} .
\end{aligned}
$$

Tanpa sistem otomatisasi, energi yang digunakan adalah sebagai berikut:

$$
\begin{aligned}
& \text { Lampu } \rightarrow 1,5 \mathrm{~W} \times 24 \mathrm{~h}=36 \mathrm{Wh} \\
& \text { Kipas Angin } \rightarrow 3,3 \mathrm{~W} \times 24 \mathrm{~h}=79,2 \mathrm{Wh} \\
& \text { Total pemakaian energi adalah 115,2 Wh. }
\end{aligned}
$$

Jika dibandingkan, energi yang digunakan pada sistem dengan otomatisasi memiliki selisih energi senesar 57,6 Wh dengan sistem tanpa otomatisasi. Sehingga dapat dikatakan energi yang dapat dihemat sebesar $50 \%$.

Selain dapat menghemat energi ketika rumah ditinggalkan atau lupa mematikan peralatan listrik, otomatisasi pada lampu, tirai, dan kipas angin juga memberikan beberapa keuntungan. Contohnya ketika orang sedang membaca kemudian kondisi ruangan gelap, maka lampu akan menyala secara otomatis sehingga orang tersebut tetap mendapatkan penerangan yang cukup. Selain itu, walaupun rumah dalam keadaan kosong, rumah tetap akan terlihat seperti ada penghuni sehingga diharapkan dapat meminimalisir terjadinya kejahatan.

\section{KESIMPULAN}

Berdasarkan tujuan yang ingin dicapai, maka dapat diambil kesimpulan bahwa energi listrik yang digunakan pada sistem otomatisasi lampu, tirai, dan kipas angin dapat dihemat sampai 50\%.

Hasil yang diperoleh pada penelitian ini belum maksimal sehingga ada beberapa hal yang harus diperhatikan pada penelitian selanjutnya. Sistem lampu, tirai, dan kipas angin otomatis yang dibuat pada penelitian ini masih dalam bentuk maket sehingga untuk implementasi ke dalam sistem yang sebenarnya perlu ditambahkan inverter supaya peralatan listrik AC dapat dioperasikan. Untuk lebih menghemat energi, sebaiknya 
kipas angin diatur menggunakan sensor suhu sehingga kipas angin dapat bekerja lebih optimal. Kemudian, digunakan logika fuzzy supaya intensitas cahaya yang dipancarkan LED sesuai dengan intensitas cahaya yang diterima LDR.

\section{UCAPAN TERIMA KASIH}

Ucapan terima kasih kami sampaikan kepada Pusat Penelitian Elektronika dan Telekomunikasi, Lembaga Ilmu Pengetahuan Indonesia (PPET-LIPI) yang telah memfasilitasi penelitian ini.

\section{DAFTar PUStaka}

[1] H. Hasan, "perancangan pembangkit listrik tenaga surya di pulau Saugi”, Jurnal Riset dan Teknologi Kelautan, vol. 10, hal. 169180, Des, 2012.

[2] K. Novianti dan C. L. Tony, "Perancangan prototipe sistem penerangan otomatis ruangan berjendela berdasarkan intensitas cahaya", dalam Proc. Seminar Nasional Teknologi Informasi, 2012, hal. 1-9.

[3] A. N. Adi, Mekatronika, Edisi Pertama, Yogyakarta, Indonesia: Graha Ilmu, 2010.

[4] B. Own, Dasar-dasar Elektronika, Bandung, Indonesia: Informatika, 2004.

[5] S. Afrie, 20 Aplikasi Mikrokontroler ATmega 8535 dan ATmega 16 Menggunakan BASCOM-AVR, Yogyakarta, Indonesia: C.V. Andi Offset, 2011.

[6] N. I. Nuzula dan Endarko, "Perancangan dan pembuatan alat ukur kekeruhan air berbasis mikrokontroler ATmega 8535", Jurnal Sains dan Semi Pomits, vol. 2, hal. 1-5, 2013.

[7] A. Rahayuningtyas, "Pembuatan sistem pengendali 4 motor DC penggerak 4 roda secara independent berbass mikrokontroler AT89C2051”, Jurnal Fisika Himpunan Fisika Indonesia, vol. 9, hal. 24-33, Des, 2009.

[8] R. Eduard, Penerapan Konsep Dasar Listrik dan Elektronika, Yogyakarta, Indonesia: Kanisius, 1999.

[9] "ATmega 8535 data sheet," ATMEL, California, Amerika Serikat.

[10] R. Syahban, Mikrokontroler Atmel AVR, Edisi Pertama, Bandung, Indonesia: Informatika, 2011. 